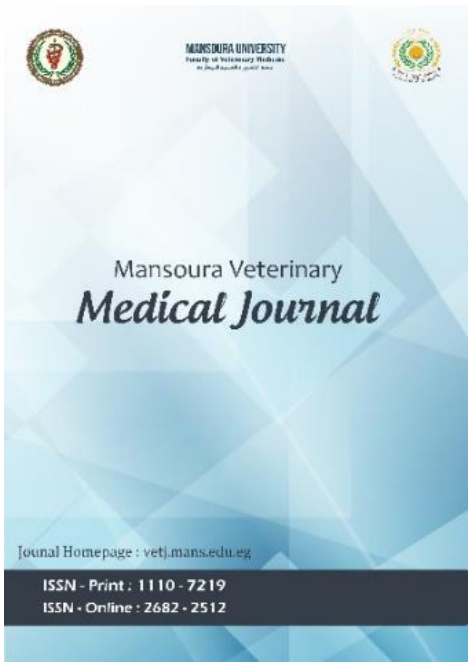

\title{
Prevalence and Antimicrobial Resistance of Bacillus cereus in Milk and Dairy Products
}

Rowayda Osama, Marwa F. E. Ahmed, Amir Abdulmawjood, Maha AlAshmawy

To cite this article: Rowayda Osama, Marwa F. E. Ahmed, Amir Abdulmawjood, Maha Al-Ashmawy. Prevalence and Antimicrobial Resistance of Bacillus cereus in Milk and Dairy Products. Mansoura Veterinary Medical Journal 2020; 21, 2: 11-18.

To link to this article: https://doi.org/10.35943/mvmj.2020.2.202

Published online: 25 June 2020

Submit your article to this journal

CrossMark data 


\title{
Prevalence and Antimicrobial Resistance of Bacillus cereus in Milk and Dairy Products
}

\author{
Rowayda Osama ${ }^{1}$, Marwa Ahmed ${ }^{2}$, Amir Abdulmawjood ${ }^{3}$, Maha Al-Ashmawy ${ }^{1}$ \\ ${ }^{1}$ Department of Food Hygiene and Control, Faculty of Veterinary Medicine, Mansoura University, Mansoura 35516, Egypt \\ ${ }^{2}$ Department of Hygiene and Zoonoses, Faculty of Veterinary Medicine, Mansoura University \\ ${ }^{3}$ Institute of Food Quality and Food Sa fety, Research Center for Emerging Infections and Zoonoses (RIZ), University of Veterinary Medicine Hannover, \\ Foundation, Bünteweg 17, D-30559 Hannover, Germany
}

\section{ARTICLE HISTORY}

\section{Received: 10.02 .2020}

Revised: 07.04 .2020

Accepted: 31.05 .2020

Address correspondence Rowayda osama; Tel: + 01000285377; E-mail: rody_osama84@yahoo.com

\section{ABSTRACT}

\begin{abstract}
Objective: To investigate the prevalence of Bacillus cereus in milk and dairy products along with detection of its antibiotic sensitivity.

Design: Descriptive study.

Samples: One hundred and fifty samples of market milk, ultra high temperature milk packs (UHT), condensed milk, Milk powder, Damietta cheese, Kariesh cheese and Ras cheese.

Procedures: Samples were examined for isolation and identification of Bacillus spp. via direct and indirect isolation, molecular examination and antimicrobial resistance. Further molecular examination was carried out in 46 isolates to detect $\mathrm{hblA}, \mathrm{hblC}, \mathrm{hblD}$, nheA, nhe $B$ and $n h e C$ genes

Results: The prevalence of $B$. cereus by direct isolation was $52 \%, 13.3 \%, 10 \%, 8 \%, 44 \%, 0 \%$ and $16 \%$ in market milk, ultra high temperature milk packs (UHT) , condensed milk, Milk powder, Damietta cheese, Kariesh cheese and Ras cheese, respectively, whereas its prevalence by indirect isolation was $64 \%, 20 \%$, $20 \%, 48 \%, 52 \%, 40 \%$ and $36 \%$ in market milk, ultra high temperature milk packs (UHT) , condensed milk, Milk powder, Damietta cheese, Kariesh cheese and Ras cheese, respectively. B. cereus isolates were $100 \%$ resistant to colistin (CT), ampicillin (AM) and amoxicillin (AML). However, $83.01 \%$ were resistant to ampicillin-sulbactum (SAM), 67.9\% resistant to streptomycin (S), 45.2\% resistant to spiramycin (SP), 35.8\% resistant to lincomysin (MY), 22.6\% resistant to tetracyclin (TE), and 5.6\% resistant to erythromycin (E). A prevalence of $58.6 \%$ for hblA, $h b l C$ and $h b / D$ was recorded, while a prevalence of $86.9 \%, 93.4 \%$ and $89.1 \%$ for nhe $A$, nhe $B$ and nhe $C$ was recorded.

Conclusion and clinical relevance: This study provides data on prevalence, contamination level and antibiotic sensitivity of $B$. cereus in milk and its products, suggesting a potential risk to health and the dairy industry.
\end{abstract}

Keywords: Bacillus cereus, milk, Dairy product, Antimicrobial susceptibility, Prevalence.

\section{INTRODUCTION}

The milk and its products are the most important source of food for human as they contain most of the nutrients required [1] . However, they represent a potential source of many organisms, including $B$. cereus that adversel yi mpacts both the public health as well as the economy of the dairy industry. Environment plays an important role in milk contamination including soil, bedding, air, feed and faeces of animal and human [2]. Furthermore, poor hygiene during milking and the subsequent handling of the milk increases the risk of contamination with bacteria [3]. Different kinds of bacteria including aerobic psychrotrophic, Gram-negative bacteria, heterofermenta tive lactobacilli, and spore forming bacteria are considered to be the most frequent pathogens contaminating the milk [4].
Spore formation of some sort of bacteria is a method of withstand unfavorable conditions as sever dryness, subzero temperatures and boiling. Because of these facts, spores are very problematic aspects of spore forming pathogens such as Bacillus cereus, especially in food production and technology [5].

B. cereus is Gram-positive, motile, aerobic-to-facultative, spore-forming rod that is widely found in food and the environment. It produces spores, enterotoxins and lecithinase enzyme. It is mainly present in soil, milk, cereals, spices and other dried foodstuffs $[6,7]$.

As one of widely existing bacteria in the environment, $B$. cereus is a causative agent of food poisoning [8]. It has been al so found that Bacillus cereus is wi delys pread in soil, food and in the human intestine [9]. Moreover, $B$. cereus has been 
related food poisoning [10]. According to the European Food Sa fety Authori ty report on food-borne outbreaks, B. cereus has been found the causative agent in 77 outbreaks and $17.1 \%$ of the cases due to bacterial toxins [11] .

Consequently, the current work aims to investigate the prevalence of $B$. cereus in milkand dairy products by using both conventional and molecular techniques along with detection of antibiotic sensitivity in order to select the appropriate antibiotics for outbreak control.

\section{MATERIALS AND METHODS}

\subsection{Sample Collection}

One hundred and fifty samples were randomly obtained including: market milk, Milk powder, Da mietta cheese, Kariesh cheese and Ras cheese (25 each). In addition, 15 ultra-high temperature milk (UHT) and 10 condensed milk packs. These samples were as eptically collected from different localities of Dakahlia province, Egypt in clean, dry and sterile containers, then immediately shipped in ice boxat 4 으 to the laboratory for $t$ analysis at the same day of collection

\subsection{Quantitative enumeration of Bacillus species}

Quantitative enumeration of Bacillus species was performed according to standard method [12]. Briefly, each sa mple was thoroughly mixed prior to examination, then $25 \mathrm{ml}$ (or g) from each sample was as eptically added to $225 \mathrm{ml}$ of nutrient broth (Oxoid, UK). From this homogenate, $\left(10^{-1}\right)$ first dilution, $1 \mathrm{ml}$ aliquot was taken to prepare serial dilutions till $10^{-6}$.

From each previously prepared dilution, $0.1 \mathrm{ml}$ aliquot was as eptically i noculated onto $B$. cereus selective agar base (Oxoid, UK), supplemented with polymyxin B $(50,000 \mathrm{IU} / 500 \mathrm{ml}$ medium) and egg yolk emulsion ( $25 \mathrm{ml} / 500 \mathrm{ml}$ medium) in duplicates and then the inoculated plates were incubated at 35 ㅇ $\mathrm{C}$ for $48 \mathrm{~h}$. The plates were examined for characteristic $B$. cereus col onies characterized by being l arge ( $3-7 \mathrm{~mm}$ diameter), dull and turquoise to peacock blue surrounded by a good egg yolk precipitation of the same color due to lecithinase production. Other members of the Bacillus group a re mannitol positive and appeared as green or yellow colonies with no lecithinase production. Subsequently, the average numbers of colony forming units (cfu) from the presumptive plates with 25250 colonies were used for calculating the total cultural bacteria per gm or $\mathrm{ml}$ of the sample.

\subsection{Qualitative detection of B. cereus}

For indirect isolation of $B$. cereus previously prepared homogena te were incubated at $35^{\circ} \mathrm{C}$ for $24 \mathrm{~h}$ then strea ked on $B$. cereus selective agar base plates, incubated as mentioned above and examined for $B$. cereus colonies characteristic.

\subsection{Identification of Bacillus species}

The sus pected Bacillus spp. colonies were purified a nd identified via biochemical tests such as sugar fermentation tests, Nitrate reduction test and a naerobic growth on blood agar [12].

\subsection{Antimicrobial susceptibility testing}

Antimicrobial susceptibility patterns of the recovered $B$. cereus is olates were determined by disc diffusion method using Mueller-Hinton agar [13]. Overnight-grown cultures in nutrient broth were prepa red and swapped a cross Mueller-Hinton agar. The a ntibiotic discs were placed a septically on it and incubated at $37^{\circ} \mathrm{C}$ for $24 \mathrm{~h}$. Strains were evaluated as susceptible, intermediate or resistance based on Clinical and Laboratory Standards Institute (CLSI) guidelines [14] .

The following antimicrobials (manufactured by Oxoid) were us ed: colistin (CT) $25 \mu \mathrm{g}$, lincomysin (MY) $10 \mu \mathrm{g}$, ampicillin (AM) $25 \mu \mathrm{g}$, pefloxacin (PEF) $5 \mu \mathrm{g}$, norfloxacin (NOR) $5 \mu \mathrm{g}$, neomycin (N) $10 \mu \mathrm{g}$, ampicillin-sulbactum (SAM) 30 $\mu \mathrm{g}$, tetracyclin (TE) $30 \mu \mathrm{g}$, a moxicillin (AML) 10 $\mu$ g, genta mycin (GN) $30 \mu \mathrm{g}$, cephradine (CE)30 $\mu \mathrm{g}$, spiramycin (SP) 100 $\mathrm{gg}$,

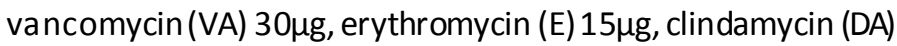
$10 \mu \mathrm{g}$ and streptomycin (S) $25 \mu \mathrm{g}$.

\subsection{Detection of $h b l$ and nhe toxine genes}

\subsubsection{DNA extraction}

Pure Colonies from the overnight culture on Columbia agar plates containing sheep blood (Oxoid, Wesel, Germany) were used for DNA extraction guided by the manufacturer's instructions for Gram-positive bacteria with the DNeasy Blood and Tissue Kit (Qiagen, Germany) following the manufacture guidelines. Finally, DNA concentration was measured with nanodrop 2000C (Thermo Fisher Scientific, Germany) at $260 \mathrm{~nm}$ and stored at $-20^{\circ} \mathrm{C}$ until used for PCR amplification.

Table1. Oligonucleotide primers used in DNA-based PCR of Bacillus isolates.

\begin{tabular}{|c|c|c|c|c|}
\hline \multicolumn{2}{|c|}{$\begin{array}{l}\text { Gene } \\
\text { Name }\end{array}$} & $\begin{array}{l}\text { Primer } \\
\text { Name }\end{array}$ & $\begin{array}{l}\text { Primer sequences } \\
\qquad\left(5^{\prime}-3^{\prime}\right)\end{array}$ & $\begin{array}{l}\text { Gene Size } \\
\text { (bp) }\end{array}$ \\
\hline \multirow{6}{*}{$\frac{x}{0}$} & $h b / A$ & hblA-F & CAAGGTGCAGATGTTGATGC & 352 \\
\hline & & hblA-R & GAACGCCCGAATATTGAG & \\
\hline & $h b / c$ & hblC-F & AATGGTCATCGGAACTCTAT & 750 \\
\hline & & hblC-R & CTCGCTGTTCTGCTGTTAAT & \\
\hline & $h b / D$ & hblD-F & AATCAAGAGCTGTCACGAAT & 410 \\
\hline & & hblD-R & CACCAATTGACCATGCTAAT & \\
\hline \multirow{6}{*}{ 汖 } & nheA & nheA-F & TACGCTAAGGAGGGGCA & 500 \\
\hline & & nheA-R & GTTTTTATTGCTTCATCGGCT & \\
\hline & nheB & nheB-F & CTATCAGCACTTATGGCAG & 770 \\
\hline & & nheB-R & ACTCCTAGCGGTGTTCC & \\
\hline & & nheC-F & CGGTAGTGATTGCTGGG & 580 \\
\hline & nhec & nheC-R & CAGCATTCGTACTTGCCAA & \\
\hline
\end{tabular}




\subsubsection{Toxin-genotyping}

All primers in the current study were utilized according to Mel nick et al. [15], and were added to the reaction mixture at a concentration of $10 \mathrm{pmol} / \mu \mathrm{l}$ (Table 1$)$. Each PCR reaction mixtures $(25 \mu \mathrm{l})$ consisted of $1 \mu \mathrm{l}$ primer $1(10 \mathrm{pmol} / \mu \mathrm{l}), 1 \mu \mathrm{l}$ primer $2(10 \mathrm{pmol} / \mu \mathrm{l}), 12.5 \mu \mathrm{l}$ PCR master mix (Red'y'Gold Mix, Eurogentec, Köln Germany) and $8.5 \mu \mathrm{l}$ of nuclease free water. Finally, $2 \mu$ l DNA were added to each reaction tube. The PCR was carried out in a thermal cycler (T3000 Thermocycler, Biometra, Goettingen, Germany) started with an initial denaturation step at $94^{\circ} \mathrm{C}$ for $5 \mathrm{~min}$, followed by 35 cycles at $94^{\circ} \mathrm{C}$ for $30 \mathrm{~s}, 55^{\circ} \mathrm{C}$ for $30 \mathrm{~s}$ and $45 \mathrm{sec}$ at $72^{\circ} \mathrm{C}$ followed by a final extension incubation of $72^{\circ} \mathrm{C}$ for $5 \mathrm{~min}$. The presence of amplification products was determined by loading of $10 \mu \mathrm{l}$ of the reaction product in a $2 \%$ agarose gel (Pequlab, Erlangen, Germany) and el ectrophoresis was performed for $120 \mathrm{~min}$ at $10 \mathrm{volt} / \mathrm{cm}$ with Tris acetate-electrophoresis buffer $1 \mathrm{xTBE}$ buffer (Tris, Boric acid and Disodium EDTA) and a 100-2,000 bp DNA ladder (Roche, ,Germany) as mol ecular marker.

B.cereus DSM 4384 and B. toyonensis BCT7112T served as positive control. Also, Staphylococcus aureus DSM 2569 was us ed as a negative control. Reference strains were obtained from Research Center for Emerging Infections and Zoonoses (RIZ), University of Veterinary Medicine Ha nnover, Germany.

\section{RESULTS}

The total bacillus count in market milk, ultra high tempera ture milkpacks (UHT), condensed milk, Milk powder, Damietta cheese, Kariesh cheese and Ras cheese were $5.4 \times 10^{5} \pm 1.09 \times 10^{5}, 1.3 \times 10 \pm 9,7 \times 10 \pm 4.2 \times 10,4.5 \times 10^{2} \pm 1.6 \times 10^{2}$, $2.3 \times 10^{5} \pm 8.5 \times 10^{4}, 1.5 \times 10^{6} \pm 2.4 \times 10^{5}$ and $3.8 \times 10^{5} \pm 6.6 \times 10^{4} \mathrm{cfu} / \mathrm{ml}$ or $\mathrm{g}$, respectively (.Table 2 ).

Table2. Total Bacillus count in milk and dairy products.

\begin{tabular}{|c|c|c|c|c|c|c|}
\hline \multirow{2}{*}{$\begin{array}{l}\text { Milk and } \\
\text { dairy } \\
\text { products }\end{array}$} & \multirow{2}{*}{$\begin{array}{l}\text { Sam } \\
\text { ple }\end{array}$} & \multirow{2}{*}{$\begin{array}{c}+ \text { ve } \\
\text { sample } \\
\text { no }\end{array}$} & \multirow{2}{*}{$\begin{array}{l}\text { Min } \\
\%\end{array}$} & \multirow[t]{2}{*}{$\operatorname{Max}$} & \multicolumn{2}{|c|}{ Mean \pm SE } \\
\hline & & & & & & \\
\hline Market milk & 25 & 25 & $100 \%$ & $4.3 \times 10^{4}$ & $\begin{array}{l}1.7 \times 10 \\
6\end{array}$ & $\begin{array}{l}5.4 \times 10^{5} \pm 1.09 x \\
10^{5}\end{array}$ \\
\hline UHT & 15 & 2 & $\begin{array}{l}13.3 \\
\%\end{array}$ & $1.0 \times 10^{2}$ & $\begin{array}{l}1.0 \times 10 \\
2\end{array}$ & $1.3 \times 10 \pm 9$ \\
\hline $\begin{array}{l}\text { Condensed } \\
\text { milk }\end{array}$ & 10 & 3 & $30 \%$ & $1.0 \times 10^{2}$ & $\begin{array}{l}4.0 \times 10 \\
2\end{array}$ & $\begin{array}{l}7.0 \times 10 \pm \\
4.2 \times 10\end{array}$ \\
\hline Milk powder & 25 & 17 & $68 \%$ & $1.0 \times 10^{2}$ & $\begin{array}{l}3.5 \times 10 \\
3\end{array}$ & $\begin{array}{l}4.5 \times 10^{2} \pm 1.6 \times 1 \\
0^{2}\end{array}$ \\
\hline $\begin{array}{l}\text { Damietta } \\
\text { cheese }\end{array}$ & 25 & 21 & $84 \%$ & $6.0 \times 10^{3}$ & $\begin{array}{l}1.6 \times 10 \\
6\end{array}$ & $\begin{array}{l}2.3 \times 10^{5} \pm 8.5 \times 1 \\
0^{4}\end{array}$ \\
\hline $\begin{array}{l}\text { Kariesh } \\
\text { cheese }\end{array}$ & 25 & 25 & $100 \%$ & $1.6 \times 10^{4}$ & $\begin{array}{l}4.2 \times 10 \\
6\end{array}$ & $\begin{array}{l}1.5 \times 10^{6} \pm 2.4 \times 1 \\
0^{5}\end{array}$ \\
\hline Ras cheese & 25 & 25 & $100 \%$ & $1.0 \times 10^{4}$ & $\frac{1.2 \times 10}{6}$ & $\begin{array}{l}3.8 \times 10^{5} \pm 6.6 \times 1 \\
0^{4}\end{array}$ \\
\hline
\end{tabular}

(UHT): ultr high temperature.

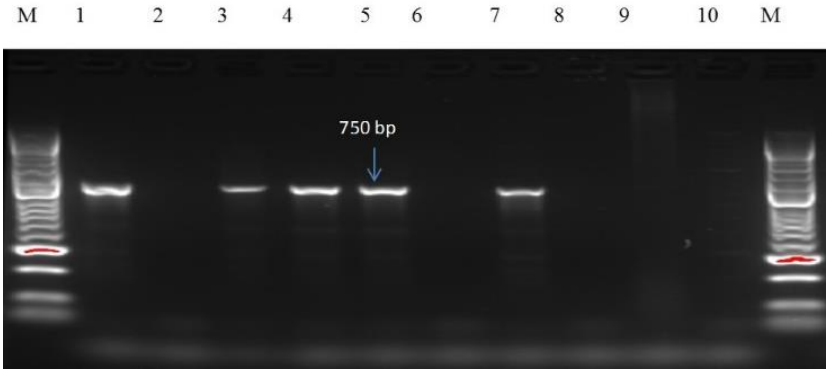

Figure 1. Typical a mplification of hbl $\mathrm{C}$ gene, lanes 1 to 6 show positive result except number 2 and 6,7 and 8 control positive, lane 9 control negative. M marker $100 \mathrm{bp}$ ladder (Promega).

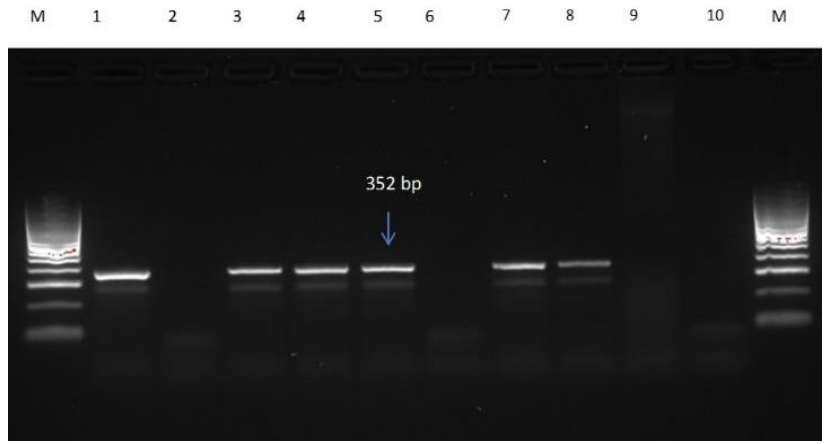

Figure 2. Typical amplification of hbl A gene, lanes 1 to 6 show positive result except number 2 and 6,7 and 8 control positive, lane 9 control negative. $\mathrm{M}$ marker $100 \mathrm{bp}$ ladder (Promega).

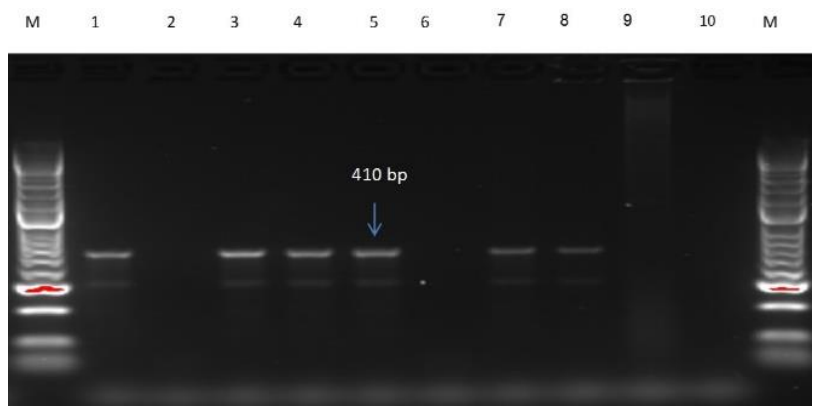

Figure 3. Typical amplification of hbl $D$ gene, lanes 1 to 6 show positive result except number 2 and 6,7 and 8 control positive, lane 9 control negative. M marker 100bp ladder (Promega).

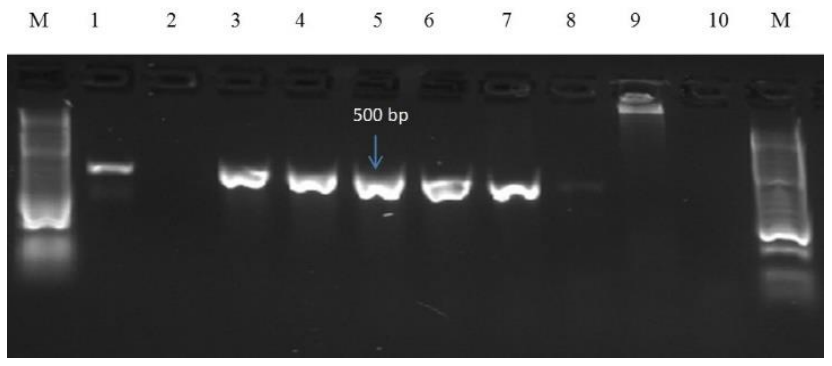

Figure 4. Typical amplification of nhe A gene Lanes from 1 to 6 show positive result except number 2, 7 and 8 control positive, Lane 9 control negative, $\mathrm{M}$ marker $100 \mathrm{bp}$ ladder (Promega). 


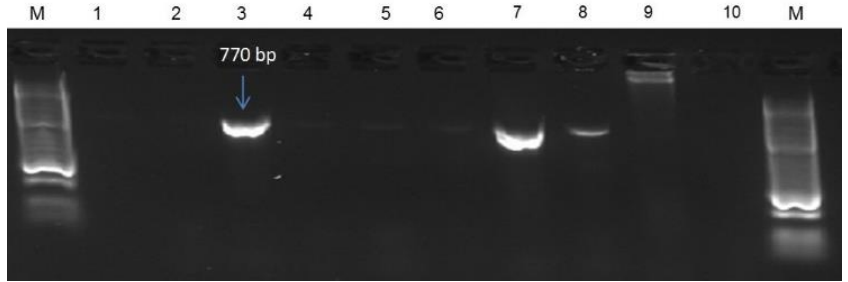

Figure 5. Typical amplification of nhe $B$ gene, number 3 is positive, 7 and 8 control positive, Lane 9 control negative, $\mathrm{M}$ marker $100 \mathrm{bp}$ ladder (Promega).

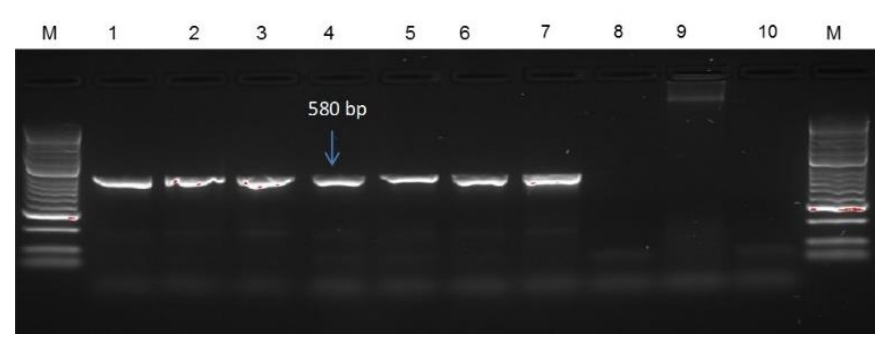

Figure 6. Typical a mplification of nhe $\mathrm{C}$ gene Lanes from 1 to 6 show positive result, 7 and 8 control positive, Lane 9 control negative, $M$ marker 100bp ladder (Promega).

Table 3 shows the prevalence of Bacillus spp. In eamined samples. The number of positive raw milk samples with Bacillus spp. was $100 \%$ ( $76 \%$ B. subtilis, $36 \%$ B. pumilus, $52 \%$ B. cereus and $2 \%$ B. lichenformis)

The number of positive Bacillus spp. in UHT mi lk samples was $20 \%$ divided in $6.6 \%$ B. subtilis, $13.3 \%$ B. cereus while both $B$. pumilus and $B$. lichenformis were not detected. In condensed milk, the positive samples for Bacillus spp. were $30 \%$ ( $30 \% B$. subtilis, $10 \%$ B. pumilus, $10 \%$ B. cereus), while $B$. lichenformis was not detected.

In milk powder the Bacillus spp. was detected in $68 \%$ of samples (64\% B. subtilis, $8 \%$ B. pumilus and $8 \%$ B. cereus). However, $B$. lichenformis was not detected.

Regarding the Damietta cheese samples, our work revealed that the number of positive samples for Bacillus spp. was $84 \%$ ( $36 \%$ B. subtilis, $12 \%$ B. pumilus, $44 \%$ B. cereus and $4 \%$ B. lichenformis).

The number of positive Bacillus spp in Kariesh cheese was $96 \%$ ( $84 \%$ B. subtilis and $16 \%$ B. pumilus), whereas both of $B$. cereus and the $B$. lichenformis were not detected. Moreover, sa mples of Ras cheese were $100 \%$ positive for Bacillus spp. (92\% B. subtilis, $28 \%$ B. pumilus, $16 \%$ B. cereus and $4 \% B$. lichenformis).

Table 4 shows that the antimic robial resistance, $100 \%$ of $B$. cereus isolates were resistant to colistin, ampicillin and amoxicillin followed by $83.01 \%$ resistant to AmpicillinSulbactum, $67.9 \%$ resistant to Streptomycin, $45.2 \%$ resistant to
Spira mycin, $35.8 \%$ resistant to Lincomysin, $22.6 \%$ resistant to Tetracyclin, 5.6\% resistant to Erythromycin.

Molecular examination of 46 is olates from raw milk and Da mi etta cheese to $h b / A, C, D$ and $n h e A, B, C$ showed that 27 $(58.6 \%)$ is olates were positive to $h b / A, C, D$ genes, 35 (76\%) isolates possessed the 3 components of nhe., 26 (56.5\%) is olates were positive to 6 genes and one isolate negative to all genes.

Additionally, the present result show that $h b /$ gene was detected in (58.6\%) of the tested isolates.

\section{DISCUSSION}

The present study revealed that total Bacillus count in market milk, ultra high temperature milk packs (UHT), condensed milk, Milk powder, Damietta cheese, Kariesh cheese and Ras cheese were $5.4 \times 10^{5} \pm 1.09 \times 10^{5}, 1.3 \times 10 \pm 9$, $7 \times 10 \pm 4.2 \times 10, \quad 4.5 \times 10^{2} \pm 1.6 \times 10^{2}, \quad 2.3 \times 10^{5} \pm 8.5 \times 10^{4}$, $1.5 \times 10^{6} \pm 2.4 \times 10^{5}$ and $3.8 \times 10^{5} \pm 6.6 \times 10^{4} \mathrm{cfu} / \mathrm{ml}$ or g, res pectively. This finding indicates that $B$. cereus is a common contaminant of milk. It can contaminate milk during production, processing and handling, it founds in soil, faeces and bedding $[2,3]$.

Table 3: Comparative study between direct and indirect isolation of Bacillus spp.in milk and dairy products.

\begin{tabular}{|c|c|c|c|c|c|c|c|c|c|c|}
\hline \multirow[t]{2}{*}{ product } & \multicolumn{2}{|c|}{$\begin{array}{l}\text { Positive } \\
\text { samples \% }\end{array}$} & \multicolumn{2}{|c|}{ B. subtilis \% } & \multicolumn{2}{|c|}{$\begin{array}{c}\text { B. } \\
\text { pumilus } \\
\%\end{array}$} & \multicolumn{2}{|c|}{$\begin{array}{c}\text { B. cereus } \\
\%\end{array}$} & \multicolumn{2}{|c|}{$\begin{array}{c}\text { B. } \\
\text { lichenfor } \\
\text { mis \% }\end{array}$} \\
\hline & D & ID & D & ID & D & ID & D & ID & D & ID \\
\hline $\begin{array}{l}\text { Market } \\
\text { milk }\end{array}$ & $100 \%$ & $\begin{array}{c}100 \\
\%\end{array}$ & $76 \%$ & $\begin{array}{c}80 \\
\%\end{array}$ & $\begin{array}{l}36 \\
\%\end{array}$ & $\begin{array}{r}40 \\
\%\end{array}$ & $\begin{array}{r}52 \\
\%\end{array}$ & $\begin{array}{c}64 \\
\%\end{array}$ & $\begin{array}{l}12 \\
\%\end{array}$ & $\begin{array}{r}20 \\
\%\end{array}$ \\
\hline UHT milk & $20 \%$ & $\begin{array}{c}93 . \\
3\end{array}$ & $\begin{array}{c}6.6 \\
\%\end{array}$ & $\begin{array}{c}46 . \\
4\end{array}$ & - & $\begin{array}{l}26 . \\
6 \%\end{array}$ & $\begin{array}{l}13 \\
.3\end{array}$ & $\begin{array}{c}20 \\
\%\end{array}$ & - & $\begin{array}{c}6.6 \\
\%\end{array}$ \\
\hline $\begin{array}{l}\text { Condense } \\
\text { d milk }\end{array}$ & $30 \%$ & $\begin{array}{c}90 \\
\%\end{array}$ & $30 \%$ & $\begin{array}{c}70 \\
\%\end{array}$ & $\begin{array}{l}10 \\
\%\end{array}$ & $\begin{array}{r}20 \\
\%\end{array}$ & $\begin{array}{l}10 \\
\%\end{array}$ & $\begin{array}{c}20 \\
\%\end{array}$ & - & $\begin{array}{l}10 \\
\%\end{array}$ \\
\hline $\begin{array}{l}\text { Milk } \\
\text { powder }\end{array}$ & $68 \%$ & $\begin{array}{c}100 \\
\%\end{array}$ & $64 \%$ & $\begin{array}{c}72 \\
\%\end{array}$ & $\begin{array}{l}8 \\
\%\end{array}$ & $\begin{array}{l}12 \\
\%\end{array}$ & $\begin{array}{l}8 \\
\%\end{array}$ & $\begin{array}{c}48 \\
\%\end{array}$ & - & $\begin{array}{r}40 \\
\%\end{array}$ \\
\hline $\begin{array}{l}\text { Damietta } \\
\text { cheese }\end{array}$ & $84 \%$ & $\begin{array}{r}92 \\
\%\end{array}$ & $36 \%$ & $\begin{array}{l}44 \\
\%\end{array}$ & $\begin{array}{l}12 \\
\%\end{array}$ & $8 \%$ & $\begin{array}{r}44 \\
\%\end{array}$ & $\begin{array}{c}52 \\
\%\end{array}$ & $\begin{array}{l}4 \\
\%\end{array}$ & $8 \%$ \\
\hline $\begin{array}{l}\text { Kariesh } \\
\text { cheese }\end{array}$ & $96 \%$ & $\begin{array}{c}100 \\
\%\end{array}$ & $84 \%$ & $\begin{array}{c}80 \\
\%\end{array}$ & $\begin{array}{l}16 \\
\%\end{array}$ & $\begin{array}{l}16 \\
\%\end{array}$ & - & $\begin{array}{c}40 \\
\%\end{array}$ & - & $4 \%$ \\
\hline $\begin{array}{l}\text { Ras } \\
\text { cheese }\end{array}$ & $100 \%$ & $\begin{array}{c}100 \\
\%\end{array}$ & $92 \%$ & $\begin{array}{c}68 \\
\%\end{array}$ & $\begin{array}{l}28 \\
\%\end{array}$ & $\begin{array}{r}24 \\
\%\end{array}$ & $\begin{array}{l}16 \\
\%\end{array}$ & $\begin{array}{c}36 \\
\%\end{array}$ & $\begin{array}{l}4 \\
\%\end{array}$ & $\begin{array}{r}24 \\
\%\end{array}$ \\
\hline
\end{tabular}

D: direct isolation, ID: indirect isolation 
Table 4: Antimicrobial susceptibility pattern of Bacillus cereus $(n=53)$

\begin{tabular}{|c|c|c|c|c|c|c|}
\hline $\begin{array}{l}\text { Antimicrobial } \\
\text { agent }\end{array}$ & $\begin{array}{l}\text { S } \\
\text { No }\end{array}$ & $\%$ & $\begin{array}{l}\text { I } \\
\text { No }\end{array}$ & $\%$ & $\begin{array}{l}\text { R } \\
\text { No }\end{array}$ & $\%$ \\
\hline Colistin (CT) & - & - & - & - & 53 & $100 \%$ \\
\hline Lincomysin (MY) & - & - & 34 & $64.15 \%$ & 19 & $35.8 \%$ \\
\hline Pefloxacin (PEF) & 24 & $45.28 \%$ & 29 & $54.7 \%$ & - & \\
\hline Ampicillin (AM) & - & - & - & - & 53 & $100 \%$ \\
\hline $\begin{array}{l}\text { Norfloxacin } \\
\text { (NOR) }\end{array}$ & 47 & $88.6 \%$ & 6 & $11.3 \%$ & - & - \\
\hline Neomycin (N) & - & - & 53 & $100 \%$ & - & - \\
\hline $\begin{array}{l}\text { Ampicillin- } \\
\text { Sulbactum } \\
\text { (SAM) }\end{array}$ & - & - & 9 & $16.9 \%$ & 44 & $\begin{array}{l}83.01 \\
\%\end{array}$ \\
\hline Tetracyclin (TE) & 3 & $5.6 \%$ & 38 & $71.6 \%$ & 12 & $22.6 \%$ \\
\hline $\begin{array}{l}\text { Amoxicillin } \\
\text { (AML) }\end{array}$ & - & - & & & 53 & $100 \%$ \\
\hline Gentamycin (CN) & 11 & $20.7 \%$ & 42 & $79.24 \%$ & - & - \\
\hline Cephradine (CE) & 12 & $22.6 \%$ & 41 & $77.3 \%$ & - & - \\
\hline Spiramycin (SP) & 8 & $15.09 \%$ & 21 & $39.6 \%$ & 24 & $45.2 \%$ \\
\hline Vancomycin (VA) & - & - & 53 & $100 \%$ & - & - \\
\hline Erythromycin (E) & - & - & 50 & $94.3 \%$ & 3 & $5.6 \%$ \\
\hline $\begin{array}{l}\text { Clindamycin } \\
\text { (DA) }\end{array}$ & 6 & $11.3 \%$ & 47 & $88.6 \%$ & - & - \\
\hline Streptomycin (S) & - & - & 17 & $32.07 \%$ & 36 & $67.9 \%$ \\
\hline
\end{tabular}

S: sensitive, I: intermediate, R: resistant.

Table 5. Antimicrobial susceptibility profile of $B$. cereus $(n=53)$.

$\begin{array}{lll}\begin{array}{ll}\text { No of } \\ \text { isolates }\end{array} & \text { Antimicrobial agents } & \text { *MAR average } \\ & & \\ 3 & \mathrm{CT}, \mathrm{MY}, \mathrm{AM}, \mathrm{TE}, \mathrm{AML}, \mathrm{SAM}, \mathrm{E}, \mathrm{S} & 0.5 \\ 3 & \mathrm{CT}, \mathrm{MY}, \mathrm{AM}, \mathrm{AML}, \mathrm{SP}, \mathrm{DA}, \mathrm{S} & 0.43 \\ 3 & \mathrm{CT}, \mathrm{MY}, \mathrm{AM}, \mathrm{SAM}, \mathrm{AML}, \mathrm{SP}, \mathrm{S} & 0.43 \\ 2 & \mathrm{CT}, \mathrm{AM}, \mathrm{SAM}, \mathrm{TE}, \mathrm{AML}, \mathrm{SP}, \mathrm{S} & 0.43 \\ 3 & \mathrm{CT}, \mathrm{MY}, \mathrm{AM}, \mathrm{SAM}, \mathrm{AML}, \mathrm{SP} & 0.37 \\ 3 & \mathrm{CT}, \mathrm{AM}, \mathrm{SAM}, \mathrm{AML}, \mathrm{S}, \mathrm{SP} & 0.37 \\ 2 & \mathrm{CT}, \mathrm{AM}, \mathrm{SAM}, \mathrm{TE}, \mathrm{AML}, \mathrm{S} & 0.37 \\ 5 & \mathrm{CT}, \mathrm{MY}, \mathrm{AM}, \mathrm{SAM}, \mathrm{AML}, \mathrm{S} & 0.37 \\ 3 & \mathrm{CT}, \mathrm{AM}, \mathrm{TE}, \mathrm{AML}, \mathrm{SP} & 0.31 \\ 5 & \mathrm{CT}, \mathrm{AM}, \mathrm{SAM}, \mathrm{AML}, \mathrm{SP} & 0.31 \\ 2 & \mathrm{CT}, \mathrm{AM}, \mathrm{AML}, \mathrm{SP}, \mathrm{S} & 0.31 \\ 3 & \mathrm{CT}, \mathrm{MY}, \mathrm{AM}, \mathrm{SAM}, \mathrm{AML} & 0.31 \\ 8 & \mathrm{CT}, \mathrm{AM}, \mathrm{SAM}, \mathrm{AML}, \mathrm{S} & 0.31 \\ 6 & \mathrm{CT}, \mathrm{AM}, \mathrm{SAM}, \mathrm{AML} & 0.25 \\ 2 & \mathrm{CT}, \mathrm{AM}, \mathrm{AML}, \mathrm{S} & 0.25 \\ \text { *MAR: Multiple Antimicrobial Resistance index. } & \\ \text { colistin (CT), lincomysin (MY), pefloxacin (PEF), ampicillin (AM), norfloxacin } \\ \text { (NOR), neomycin (N), ampicillin-sulbactum (SAM), tetracyclin (TE), amoxicillin } \\ \text { (AML), gentamycin (CN), cephradine (CE), spiramycin (SP), vancomycin (VA), } \\ \text { erythromycin (E), clindamycin (DA) and streptomycin (S). }\end{array}$

Our study showed that number of positive raw milk samples with Bacillus spp. was $100 \%$ divided into $76 \% B$. subtilis, $36 \%$ B. pumilus, $52 \%$ B. cereus and $2 \%$ B. lichenformis. Similarly, B. cereus was detected in 44\% [16] ,60\% [17] , 51.6\% [18] and 60\% [19] of the tested raw milk samples.

On contrary to our results, lower incidences of $B$. cereus; $35 \%[20]$ and $30 \%$ [21] was reported in the examined samples.
Such difference may be due the high contamination of milk samples with Bacillus spp. Bacillus spp. Were found a common contaminant of milk due to their wide environmental distribution leading to milk contamination during production, handling and processing [22]. It should be noted that the Egyptian standard [23] stated that raw milk must be free from pathogenic organisms and their toxins.

In the current investigation, the number of positive Bacillus spp. in UHT milk samples was $20 \%$ (6.6\% B. subtilis, $13.3 \%$ B. cereus), while both $B$. pumilus and $B$. lichenformis were not detected in any of samples. This finding indicates contamination of UHT milk. This may occur due to the presence of heat res istant organisms that can tolerate the process of heat treatment or by contamination with spoilage organisms a fter heat treatment [24]. The detection rate of $B$. cereus in UHT milk in our study was nearly similar to that obtained by other studies that reported a rate of $13.8 \%$ [18] , 18.3\% [25] and $17.8 \%$ [26] . On the other hand, a study reported a higher incidence (61.3\%) [27]. According to the Egyptian standard [28], UHT milk must be free from pathogenic organisms and their toxins.

The present result revealed that the number of positive Bacillus samples in condensed milk was $30 \%$, ( $30 \%$ B. subtilis, $10 \%$ B. B. pumilus, $10 \%$ B. cereus), while $B$. lichenformis was not detected. Our detection rate of Bacillus cereus (10\%) was lower than that of $56 \%$ obtained in another work [29], whereas another study[30] could not detect it in their samples. Moreover, Egyptian standard [31] stated that condensed milk must be free from pathogenic organisms and their toxins.

The current study revealed that the number of positive samples for Bacillus spp. in milk powder was $68 \%$ divided into $64 \%$ B. subtilis, $8 \%$ B. pumilus and $8 \%$ B. cereus. However, B. lichenformis was not detected.Similarly, two studies obtained nearly similar results regarding milk powder contamination by B. cereus which were $10.7 \%$ [32] and $8.3 \%$ [33]. On the other hand, higher percentages of $15 \%$ [19] , 27.9\% [34] and 42\% [35] were reported. Moreover, the current finding doesn't meet the requi rement of Egyptian standard which indicates that the milk powder must be free from pathogenic organisms and toxins.

The detection of $B$. cereus in milk powder samples may be explained by the use of pas teurization and spray drying during milk powder manufacture causes induction of germination and outgrowth of $B$. cereus spores [36].

Regarding the Damietta cheese samples, our study revealed that the number of positive samples for Bacillus spp. was $84 \%$ ( $36 \%$ B. subtilis, $12 \%$ B. pumilus, $44 \%$ B. cereus and $4 \%$ B. lichenformis). B. cereus was found in $44 \%$ of the examined samples while other studies reported lower incidences of $20 \%$ [37] and 33.3\% [38] . However, another study could not detect it in the examined samples [39] . Higher incidence of $50 \%$ was al so recorded [40]. Interestingly, Egyptian standard [41] stated 
that soft cheeses like damietta cheese must be free from pathogenic organisms and their toxins.

In case of kariesh cheese samples, the number of positive Bacillus spp. was $96 \%$ ( $84 \%$ B. subtilis and $16 \%$ B. pumilus), whereas both the $B$. cereus and the $B$. lichenformis were not detected. The extent of $B$. cereus contamination depends on the effectiveness of hygienic measures applied during processing, handling and distribution of milk products [42]. The absence of $B$. cereus in our karish cheese samples comes in agreement with other reports $[39,41]$ Such absence is explained by acidity karies h cheese [43]. Contradictory, other studies reported percentages of 28\% [44] and 10\% [37]. Additionally, samples of ras cheese were $100 \%$ positive for Bacillus spp. (92\% B. subtilis, $28 \%$ B. pumilus, $16 \%$ B. cereus and $4 \%$ B. lichenformis).

Compared to our study results, both higher $(48 \%)$ and lower $(7 \%)$ incidences of $B$. cereus were detected in other studies $[45,46]$. Generally, detection of $B$. cereus in ras cheese is inconsistent with the Egyptian standard [47] which stated that hard chees e must be free from pa thogenic organisms and their toxins.

Regarding the antimicrobial resistance, $100 \%$ of $B$. cereus isolates were resistant to colistin, a mpicillin and amoxicillin followed by $83.01 \%$ resistant to Ampicillin-Sulbactum, $67.9 \%$ resistant to Streptomycin, $45.2 \%$ resistant to Spiramycin, $35.8 \%$ resistant to Lincomysin, $22.6 \%$ resistant to Tetracyclin, 5.6\% resistant to Erythromycin which agree withKim, Cho [48] who found that all $B$. cereus strains were resistant to $\beta$ - lactam including Ampicillin, Penicillin and Amoxicillin and susceptible to Ciprofloxacin, Gentamycin, Tetracycline and Vancomycin. Therefore, the use $\beta$ - lactam is ineffective for B. cereus infection, but use Norfloxacin and Ciprofloxacin may be of value.

Molecular examination of 46 isolates from raw milk and damietta cheese to $h b / A, C, D$ and nhe A, B, C shows that 27 (58.6\%) isolates were positive to $h b / A, C, D$ genes, 35 (76\%) isolates poosses the 3 components of $n h e ., 26$ (56.5\%) isolates were positive to 6 genes and one is olate nega tive to all genes. $B$. cereus secretes a group of enterotoxins which cause food poi soning symptoms (diarrheal type). These enterotoxins are hemolysin BL $(h b l)$, nonhemolytic enterotoxin (nhe) and cytotoxin K (Cytk) [49] $h b /$ is considered to be the first B. cereus enterotoxin to be characterized [50, 51]. Nonhemolytic enterotoxin nhe was characterized in Norway after an outbreak of food poisoning involving 152 people [51].

Nearly, all tes ted B. cereus strains produce $n h e$, the finding is in agreement with our results, which showd that $70 \%$ of is olates were $n$ he gene positive. Other studies $[52,53]$ found that $100 \%$ of is olates were positive to nhe gene, while it was als ofound that only less than $54.8 \%$ of isolates were positive to nhe gene [54]
The present result show that $h b /$ gene was detected in $58.6 \%$ of the tested is olates, whereas another study [52] found $\mathrm{hb} /$ genes were also highly frequent in the tes ted strains (92\%). In this study, all of the tes ted i solates contained at least one of the six genes tes ted indicating the high enterotoxigenicity of $B$. cereus and a potential risk to milk and dairy.

\section{Conclusion}

The results of the present study indicate that Bacillus spp. are established in milk and dairy products. Therefore, it is recommended use of high quality raw milk for the manufacture of milk products, proper cleaning and sanitization of equipment, employment healthy workers with health certificate in dairy industry, and effective sanitation in dairy industry in order to minimize contamination of milk and dairy products.

\section{Conflict of interest statement}

The a uthors declare that there is no any conflict of interest in the current res earch work.

\section{Research Ethics Committee permission}

The current research work was conducted according to standards of Research Ethics committee, Faculty of Veterinary Medicine, Mansoura University.

\section{Authors' contribution}

Rowayda os ama performed the experiment and drafted the MS. Marwa F. E. ahmed and Amir Abdulmawjood performed the molecular experiment in Institute of Food Quality and Food Safety, Research Center for Emerging Infections and Zoonoses (RIZ), University of Veterinary Medicine Hannover, Germany. Maha Al-Ashmawy supervised the whole research work and revised the MS.

\section{REFERENCES}

[1] Waser M, Michels KB, Bieli C, Flöistrup H, Pershagen G, von Mutius E, et al. Inverse association of farm milk consumption with asthma and allergy in rural and suburban populations across Europe. Clin Exp Allergy 2007;37:661-70. https://doi.org/10.1111/j.1365-2222.2006.02640.x

[2] Velázquez-Ordoñez V, Valladares-Carranza B, Tenorio-Borroto E, TalaveraRojas M, Antonio Varela-Guerrero J, Acosta-Dibarrat J, et al. Microbia Contamination in Milk Quality and Health Risk of the Consumers of Raw Milk and Dairy Products. Nutrition in Health and Disease - Our Challenges Now and Forthcoming Time: IntechOpen 2019. https://doi.org/10.5772/intechopen. 86182

[3] Elmoslemany AM, Keefe GP, Dohoo IR, Wichtel JJ, Stryhn H, Dingwell RT. The association between bulk tank milk analysis for raw milk quality and onfarm management practices. Prev Vet Med 2010;95:32-40. https://doi.org/10.1016/j.prevetmed.2010.03.007

[4] Ledenbach LH, Marshall RT. Microbiological Spoilage of Dairy Products. Compendium of the Microbiological Spoilage of Foods and Beverages: Springer New York; 2009. p. 41-67. https://doi.org/10.1007/978-1-44190826-1_2

[5] Soni A, Oey I, Silcock P, Bremer P. BacillusSpores in the Food Industry: A Review on Resistance and Response to Novel Inactivation Technologies. Compr Rev Food Sci F 2016;15:1139-48. https://doi.org/10.1111/1541 4337.12231 
[6] Hwang J-Y, Park J-H. Characteristics of enterotoxin distribution, hemolysis, lecithinase, and starch hydrolysis of Bacillus cereus isolated from infant formulas and ready-to-eat foods. J Dairy Sci 2015;98:1652-60. https://doi. org/10.3168/jds.2014-9042

[7] Tewari A, Abdullah S. Bacillus cereus food poisoning: international and Indian perspective. J Food Sci Tech 2014;52:2500-11. https://doi.org/10.1007/s13197-014-1344-4

[8] Rasko DA, Altherr MR, Han CS, Ravel J. Genomics of theBacillus cereusgroup of organisms. FEMS Microbiol Rev 2005;29:303-29. https://doi. org/10.1016/j.fmrre.2004.12.005

[9] Bottone EJ. Bacillus cereus, a Volatile Human Pathogen. Clin Microbiol Rev 2010;23:382-98. https://doi.org/10.1128/CMR.00073-09

[10] Hauge S. FOOD POISONING CAUSED BY AEROBIC CPORE-FORMING BACILU. $J$ App Bacteriol 1955;18:591-5. https://doi.org/10.1111/j.13652672.1955.tb02116.x

[11] Authority EFS. The Community Summary Report on Trends and Sources of Zoonoses, Zoonotic Agents, Antimicrobial resistance and Foodborne outbreaks in the European Union in 2006. EFSA J 2007;5. https://doi.org/10.2903/j.efsa.2007.130r

[12] Roberts D., Greenwood. Practical food microbiology. 3rd ed. Blackwell. 2003. https://doi.org/10.1002/9780470757512

[13] Jorgensen JH, Turnidge JD. Susceptibility Test Methods: Dilution and Disk Diffusion Methods*. Manual of Clinical Microbiology, 11th Edition: American Society of Microbiology p. 1253-73. https://doi. org/10.1128/9781555817381.ch71

[14] CLSI. Clinical and Laboratory Standard Institute (CLSI) Performance Standards for Antimicrobial Susceptibility Testing. 20th Informational Supplement CLSI document M100-S20 CLSI, Wayne, PA: Clinical and Laboratory Standard Institute; Available from: https://clsiorg/. 2010.

[15] Melnick RL, Testen AL, Poleatewich AM, Backman PA, Bailey BA. Detection and expression of enterotoxin genes in endophytic strains of Bacillus cereus. Lett Appl Microbiol 2012;54:468-74. https://doi. org/10.1111/j.1472-765X.2012.03232.x

[16] ABDALLAH MIM. Aerobic sporeforming bacteria in milk and some dairy products in Damietta Governorate. MD Thesis Vet Sci Zagazig University. 1997.

[17] Martins, Albuquerque. Quality of commercial pasteurized type C milks in Fortaleza. Bacteria with multiple resistance to antibiotics. Higiene Alimentar 1999;13: 39-42.

[18] Vidal AMC, Rossi Junior OD, Abreu ILd, Bürger KP, Cardoso MV, Gonçalves ACS, et al. Detection of Bacillus cereus isolated during ultra high temperature milk production flowchart through random amplified polymorphic DNA polymerase chain reaction. Ciência Rural 2015;46:28692. https://doi. org/10.1590/0103-8478cr20141539

[19] Mohamed AS, Alnakip ME, Aal SF. Occurrence of Bacillus cereus in raw milk and some dairy products in Egypt. Japanese J Vet Res 2016;64:S95-S103.

[20] Te Giffel M, Beumer R. Isolation, identification and characterization of Bacillus cereus in the dairy industry. Tijdschrift voor diergeneeskunde 1998;123:628

[21] Hassan GM, Al-Ashmawy MAM, Meshref AMS, Afify SI. STUDIES ON ENTEROTOXIGENICBACILLUS CEREUSIN RAW MILK AND SOME DAIRY PRODUCTS. J Food Safety 2010. https://doi.org/10.1111/j.1745 4565.2010.00226.x

[22] Walker SJ. Major spoilage micro-organisms in milk and dairy products. Int J Dairy Technol 1988;41:91-2. https://doi.org/10.1111/j.1471 0307.1988.tb00606.x

[23] ES. Egyptian Standards. Raw milk. Egyptian Organization for Standardization and quality Control ES: 154-2001.

[24] Hassan A, Amjad I, Mahmood S. Microbiological and physicochemical analysis of different UHT milks available in market. African J Food Sci (ACFS) 2009;3:100-6.

[25] Bahout A. Prevalence of Bacillus species in UHT milk. Assiut Vet Med J. 2000;42:47-53.

[26] Sobeih A, Al-Hawary I, Aman I. Microbiological quality of milk and ice cream sold in Kafr El-Sheikh and El-Gharbia governorates. Minufyia Vet J 2002;2:79-89.
[27] Ali ZI, Saudi AM, El-Esawy HA. Incidence and public health significance of aerobic spore forming bacteria in Ultra Heat Treated (UHT) milk.

[28] ES. UHT milk. Egyptian Standards Egyptian Organization for Standardization and quality Control ES: 1623-2005.

[29] Abdel-Hameed. Studies on Bacillus cereus and related species in heat treated milk and some milk products. Fac Vet Med, Assuit univerisity. 2004

[30] Abdallah MIMI. Hygienic quality of concentrated and raw milks sold in Damietta governorate. 2002.

[31] ES. Condensed milk. Egyptian Standards Egyptian Organization for Standardization and quality Control ES: 1008-2000.

[32] Hammer P, Wiebe C, Walte H, Teufel P. Incidence and properties of Bacillus cereus strains from a milk powder plant-risk consideration and quality assurance. Kieler Milchwirtschaftliche Forschungsberichte 2001;53:123-46.

[33] Di Pinto A, Bonerba E, Bozzo G, Ceci E, Terio V, Tantillo G. Occurence of potentially enterotoxigenic Bacillus cereus in infant milk powder. Eur Food Res Technol 2013;237:275-9. https://doi.org/10.1007/s00217013-1988-8

[34] AbdelKhalek. Incidence and characterization of - enterotoxigenic Bacillus cereus in some dairy products. Suez Canal VetMedJ ; 5: 1-10 2002.

[35] Rodriquez MH, Barrett EL. Changes in Microbial Population and Growth of Bacillus cereus During Storage of Reconstituted Dry Milk. J Food Prot 1986;49:680-6. https://doi. org/10.4315/0362-028X-49.9.680

[36] Arevalo-Rodriguez I, Smailagic N, Roqué I Figuls M, Ciapponi A, SanchezPerez E, Giannakou A, et al. Mini-Mental State Examination (MMSE) for the detection of Alzheimer's disease and other dementias in people with mild cognitive impairment $(\mathrm{MCl})$. The Cochrane database of systematic reviews. 2015;2015:CD010783-CD.

https://doi.org/10.1002/14651858.CD010783.pub2

[37] El Sayed M, Hosny I, El Kholy W, El Dairouty R, Mohamed HS. Microbiological evaluation of Egyptian white soft cheeses style. J American Sci 2011;7:517-26.

[38] El-Gamal M, El Dairouty R, Okda A, Salah SH, El-Shamy S. Incidence and interrelation of Cronobacter sakazakii and other foodborne bacteria in some milk products and infant formula milks in Cairo and Giza area. World Appl SciJ 2013;26:1129-41.

[39] Ibrahim GA, Sharaf OM, El-Khalek ABA. Microbiological quality of commercial raw milk, domiati cheese and kareish cheese. Middle East Journal Appl Sci 2015;5:171-6.

[40] Helmy ZA, Abd-El-Bakey A, Mohamed El. Occurrence of Bacillus cereus in milk and milk products in Egypt. Zentralblatt für Mikrobiologie 1984;139:129-33. https://doi.org/10.1016/S0232-4393(84)80006-2

[41] ES. Egyptian Standards. Soft cheese. Egyptian Organization for Standardization and quality Control. ES: 1008-2000.

[42] FDA. Food and Drug administration (FDA), Center for Food Safety and Applied Nutrition (SFSAN). Bad book bug: Food borne Pathogenic Microorganisms and Natural Toxins Handbook. 2000.

[43] Clavel T, Carlin F, Lairon D, Nguyen-The C, Schmitt P. Survival of Bacillus cereus spores and vegetative cells in acid media simulating human stomach. J App Microbiol 2004;97:214-9. https://doi.org/10.1111/j.1365 2672.2004.02292.x

[44] Sadek ZI, Fathi FA, Salem M. Incidence, survival and biocontrol of psychrotrophic Bacillus cereus and its potential for toxin production in milk and Tallaga cheese. Polish J Food Nutr Cci 2006;15:419-25.

[45] Nawar. Toxicoinfection organisms in milk and some street- vended dairy products. Fac vet med Alexandria University, 2007.

[46] Sadek Z, Hosny I, El-Kholy W, El-Dairouty R. Comparative investigations for detection of foodborne microorganisms in Egyptian hard cheese" Ras" using conventional and fast biochemical tests. Global Veterinaria 2009;3:189-95

[47] ES. Egyptian Standards. Rascheese.Egyptian Organization for Standardization and quality Control ES 1183-1998.

[48] Kim C-W, Cho S-H, Kang S-H, Park Y-B, Yoon M-H, Lee J-B, et al. Prevalence, Genetic Diversity, and Antibiotic Resistance ofBacillus cereuslsolated from Korean Fermented Soybean Products. J Food Sci 2014;80:M123-M8 https://doi.org/10.1111/1750-3841.12720

[49] Sastalla I, Fattah R, Coppage N, Nandy P, Crown D, Pomerantsev AP, et al. The Bacillus cereus $\mathrm{Hbl}$ and Nhe Tripartite Enterotoxin Components 
Assemble Sequentially on the Surface of Target Cells and Are Not Interchangeable. PLOS ONE 2013;8:e76955. https://doi.org/10.1371/journal. pone.0076955

[50] Beecher DJ, Macmillan JD. Characterization of the components of hemolysin BL from Bacillus cereus. Infect Immun 1991;59:1778-84. https://doi.org/10.1128/IAl.59.5.1778-1784.1991

[51] Beecher DJ, Wong AC. Improved purification and characterization of hemolysin BL, a hemolytic dermonecrotic vascular permeability factor from Bacillus cereus. Infect Immun 1994;62:980-6. https://doi.org/10.1128/IAI.62.3.980-986.1994

[52] Guinebretiere $\mathrm{MH}$, Broussolle V, Nguyen-The C. Enterotoxigenic Profiles of Food-Poisoning and Food-Borne Bacillus cereus Strains. J Clin Microbiol 2002;40:3053-6. https://doi.org/10.1128/JCM.40.8.3053-3056. 2002

[53] Andersen Borge GI, Skeie M, Sørhaug T, Langsrud T, Granum PE. Growth and toxin profiles of Bacillus cereus isolated from different food sources.
International J Food Microbiol 2001;69:237-46. https://doi.org/10.1016/S0168-1605(01)00500-1

[54] Abbas BA, Khudor MH, Saeed BM. Detection of hbl, nhe and bceT Toxin Genes in Bacillus cereus Isolates by Multiplex PCR. Int J Curr Microbiol App Sci. 2014;3:1009-16. 